\title{
CONTACT FREQUENCIES BETWEEN GRANDPARENTS AND GRANDCHILDREN IN A MODERN SOCIETY: ESTIMATES OF THE IMPACT OF PATERNITY UNCERTAINTY
}

\author{
Thomas V. Pollet ${ }^{1}$, DANiEl NeTtle* AND MARK NeLISSEN** \\ *Evolution and Behaviour Research Group, Division of Psychology, \\ Newcastle University, UK \\ **Behavioural Biology, University of Antwerp, Belgium
}

\begin{abstract}
Evolutionary theory suggests that maternal grandparents will invest more in their grandchildren than paternal grandparents, due to the difference between the certainty of maternity and the uncertainty of paternity. Tests of this prediction have tended to use retrospective ratings by grandchildren rather than self-reported behaviour by grandparents. Using a large-scale dataset from the Netherlands, we show significant differences between maternal and paternal grandparents in terms of frequencies of contact with their grandchildren, while controlling for a wide range of other variables. Our results show biases consistent with the paternity uncertainty hypothesis.
\end{abstract}

Keywords: grandparental solicitude, paternity uncertainty, family relations, social interaction

\section{INTRODUCTION}

Kinship has been claimed to be of relatively low importance for social interaction in modern societies (BECK 1993; BECK and BECK-GERNSHEIM 2002; GIDDENS 1991). Yet, from an evolutionary perspective, we should expect biological relatedness to be an enduringly powerful determinant of social investments, even in modern societies (HAMILTON 1964). In historical European populations, grandmothers have been found to provide significant benefits for their grandchildren (LAHDENPERÄ et al. 2004; RAGSDALE 2004). Similar beneficial effects were found for a contemporary population in rural Ethiopia and Gambia (GIBSON and MACE 2005; SEAR et al. 2000; SEAR et al. 2002). Since maternal grandparents are related to their grandchildren by certain maternity rather than uncertain paternity, we should expect their levels of investment to be higher than those of their paternal-line counterparts.

Consistent with predictions based on paternity uncertainty, differences in solicitude between maternal and paternal grandparents have been found in historical (VOLAND and BEISE 2002) and modern societies (EULER and WEITZEL 1996; EULER et al. 2001; MiCHALSKI and SHACKELFORD 2005; PASHOS 2000). Typically, maternal grandmothers invest most in their grandchildren followed by maternal

\footnotetext{
${ }^{1}$ Corresponding author: T.V.Pollet@ncl.ac.uk; Henry Wellcome building for Neuroecology (Newcastle University), Framlington Place, NE2 4HH, Newcastle upon Tyne, United Kingdom.
} 
grandfathers, and paternal grandmothers, with paternal grandfathers investing least (EISENBERG 1988; HOFFMAN 1979-1980, KAHANA and KAHANA 1970; ROSSI and RossI 1990). Even though paternity uncertainty in contemporary societies is assumed to be relatively low (see ANDERSON 2006), consistent differences in solicitude have been found between maternal and paternal grandparents. These differences between matrilines and patrilines have also been documented for uncles and aunts (GAULIN et al. 1997; MCBURNEY et al. 2002). In line with predictions for paternity uncertainty maternal uncles and aunts were rated more positively than paternal uncles and aunts. In general, individuals thus appear to invest more in their matriline than in their patriline.

PASHOS (2000), however, found the reverse for rural Greeks: paternal grandparents invested more than maternal grandparents. Similar effects have been found for rural areas in the USA (KING and ELDER 1995; KING et al. 2003). A possible explanation for this effect is that in rural samples inheritance of land benefits males and females differently and that solicitude measures reflect attempts by males to acquire land from grandparents (MICHALSKI and SHACKELFORD 2005).

Evolutionary studies of grandparental investment in modern societies have mainly focussed on retrospective ratings by grandchildren, rather than grandparental behaviour (CHRASTIL et al. 2006; EULER and WeITZEL 1996; EULER, HOIER and ROHDE 2001; LAHAM, GONSALKORALE and VON HIPPEL 2005; PASHOS 2000; but see MICHALSKI and SHACKELFORD 2005). The main argument for using this method has been that grandparents would give socially desirable answers and therefore would claim to treat all grandchildren equally (EULER and WEITZEL 1996; HOFFMAN 1979-1980). However, research from a family studies perspective has analysed the grandparent-grandchild dyad from the grandparent point of view, and has found consistent differences in grandparent-grandchild contact frequencies by lineage (UhleNBERG and HAMILL 1998). MiCHALSKI and SHACKELFORD (2005) have argued that contact frequencies are a poor measure for investment, mainly because they do not take into account who initiates contact. However, social network research commonly uses contact frequency measures and these measures often relate to emotional and financial support (see HOUSE, UMBERSON and LANDIS 1988). It is thus reasonable to examine contact frequency data from a grandparent perspective for evidence of lineage-based differences. We analysed a large data set from the Netherlands for lineage effects, using a multivariate design that allowed us to control for initiative of contact and a large number of other factors affecting the grandparent-grandchild tie. The variables examined, and our predictions about them, are summarized in Table 1. Following paternity uncertainty, the chief prediction of interest is that, when other factors are controlled for, there will be consistent differences in contact frequency between maternal grandmothers and paternal grandmothers/grandfathers, and between maternal grandfathers and paternal grandfathers. However, paternity uncertainty does not necessarily lead to predict that maternal grandfathers will invest more than paternal grandmothers, as is commonly found. This finding has been attributed to co-residence of grandparents (see GAULIN 
Table 1. Variables (frequencies/means) in the model and concomitant predictions

\begin{tabular}{|c|c|c|c|c|}
\hline Variables & Categories & $\begin{array}{c}\text { Frequen- } \\
\text { cies/means }\end{array}$ & Prediction & References \\
\hline $\begin{array}{l}\text { Education } \\
(3 \text { cat.) }\end{array}$ & $\begin{array}{l}\text { Incomplete, primary or } \\
\text { lower vocational } \\
\text { Secondary or higher } \\
\text { vocational } \\
\text { University or postgraduate }\end{array}$ & $\begin{array}{l}n=335 \\
n=468 \\
n=28\end{array}$ & $\begin{array}{l}\text { More contact if } \\
\text { higher educated }\end{array}$ & $\begin{array}{l}\text { BARRANTI (1985) } \\
\text { BAYDAR and BROOKS- } \\
\text { GUNN (1998) }\end{array}$ \\
\hline $\begin{array}{l}\text { Marital status } \\
\text { respondent ( } 3 \\
\text { cat.) }\end{array}$ & $\begin{array}{l}\text { Widowed } \\
\text { Divorced } \\
\text { Married }\end{array}$ & $\begin{array}{l}n=169 \\
n=101 \\
n=562\end{array}$ & $\begin{array}{l}\text { Divorced and wid- } \\
\text { owed grandparents } \\
\text { will have less con- } \\
\text { tact than married } \\
\text { grandparents. }\end{array}$ & $\begin{array}{l}\text { BAYDAR and BROOKS- } \\
\text { GUNN (1998) } \\
\text { DENHAM and SMITH } \\
(1989) \\
\text { KING (2003) } \\
\text { REITZES and MUTRAN } \\
(2004)\end{array}$ \\
\hline $\begin{array}{l}\text { Marital status } \\
\text { child }\end{array}$ & $\begin{array}{l}\text { Married } \\
\text { Cohabiting } \\
\text { (but not married) } \\
\text { Widowed } \\
\text { (no resident partner) } \\
\text { Divorced } \\
\text { (no resident partner) } \\
\text { Never married } \\
\text { (no resident partner) }\end{array}$ & $\begin{array}{l}n=682 \\
n=115 \\
n=2 \\
n=20 \\
n=12\end{array}$ & $\begin{array}{l}\text { More contact if di- } \\
\text { vorced or widowed } \\
\text { (although contin- } \\
\text { gent upon sex) }\end{array}$ & $\begin{array}{l}\text { DENHAM and SMITH } \\
(1989) \\
\text { JOHNSON (1988) }\end{array}$ \\
\hline $\begin{array}{l}\text { Urbanization } \\
\text { (respondent) } \\
\text { ( } 5 \text { cat.) }\end{array}$ & $\begin{array}{l}\text { Very strongly urbanised } \\
\left(>=2500 \mathrm{addr} / \mathrm{km}^{2}\right) \\
\text { Strongly urbanised } \\
\left(1500-2500 \mathrm{addr} / \mathrm{km}^{2}\right) \\
\text { Moderately urbanised } \\
\left(1000-1500 \mathrm{addr} / \mathrm{km}^{2}\right) \\
\text { Hardly urbanised } \\
\left(500-1000 \mathrm{addr} / \mathrm{km}^{2}\right) \\
\text { Not urbanised } \\
\left(<500 \mathrm{addr} / \mathrm{km}^{2}\right)\end{array}$ & $\begin{array}{l}n=91 \\
n=239 \\
n=172 \\
n=199 \\
n=130\end{array}$ & $\begin{array}{l}\text { More contact in } \\
\text { less urbanized re- } \\
\text { gions }\end{array}$ & $\begin{array}{l}\text { KING and ELDER } \\
(1995) \\
\text { KING et al. (2003) }\end{array}$ \\
\hline $\begin{array}{l}\text { Initiative of } \\
\text { contact }\end{array}$ & $\begin{array}{l}\text { Initiative grandparent } \\
\text { Balanced } \\
\text { Initiative parent }\end{array}$ & $\begin{array}{l}n=663 \\
n=71 \\
n=288\end{array}$ & (control variable) & $\begin{array}{l}\text { See MICHALSKI and } \\
\text { SCHACKELFORD } \\
(2005)\end{array}$ \\
\hline $\begin{array}{l}\text { Grandparent } \\
\text { type }\end{array}$ & $\begin{array}{l}\text { Maternal grandmother } \\
\text { (MGM) } \\
\text { Maternal grandfather } \\
\text { (MGF) } \\
\text { Paternal grandmother } \\
\text { (PGM) } \\
\text { Paternal grandfather (PGF) }\end{array}$ & $\begin{array}{l}n=288 \\
n=197 \\
n=215 \\
n=131\end{array}$ & $\begin{array}{l}\text { Contact will be } \\
\text { larger for MGM } \\
\text { followed by MGF, } \\
\text { PGM and PGF, } \\
\text { with PGF having } \\
\text { the least contact. }\end{array}$ & $\begin{array}{l}\text { EULER and WEITZEL } \\
(1996) \\
\text { MICHALSKI and } \\
\text { SCHACKELFORD (2005) } \\
\text { CHRASTIL et al (2006) }\end{array}$ \\
\hline $\begin{array}{l}\text { Relatedness } \\
\text { with child }\end{array}$ & $\begin{array}{l}\text { Not fully related } \\
\text { (adopted or partner's) } \\
\text { Fully related }\end{array}$ & $\begin{array}{l}n=14 \\
n=817\end{array}$ & $\begin{array}{l}\text { More contact if } \\
\text { fully related }\end{array}$ & $\begin{array}{l}\text { SANDERS and } \\
\text { TRYGSTAD (1989) }\end{array}$ \\
\hline $\begin{array}{l}\text { Geographical } \\
\text { distance }\end{array}$ & $\begin{array}{l}\text { (interval); see Dykstra et } \\
\text { al. } 2004 \text { for additional in- } \\
\text { formation }\end{array}$ & $\begin{array}{l}27.04 \mathrm{~km} \\
(\mathrm{SD}=41.99)\end{array}$ & $\begin{array}{l}\text { Less contact if in- } \\
\text { crease in distance }\end{array}$ & $\begin{array}{l}\text { LAWTON et al. (1994) } \\
\text { UHLENBERG and } \\
\text { HAMILL (1998) }\end{array}$ \\
\hline
\end{tabular}


Table 1. (continued)

\begin{tabular}{lllll}
\hline \multicolumn{1}{c}{ Variables } & \multicolumn{1}{c}{ Categories } & $\begin{array}{c}\text { Frequen- } \\
\text { cies/means }\end{array}$ & \multicolumn{1}{c}{ Prediction } & References \\
\hline $\begin{array}{l}\text { Number of } \\
\text { ever born } \\
\text { children }\end{array}$ & $\begin{array}{l}\text { (interval) (includes } \\
\text { adopted children) }\end{array}$ & $\begin{array}{l}2.68 \text { children } \\
(\mathrm{SD}=1.15)\end{array}$ & $\begin{array}{l}\text { Less contact if } \\
\text { more children }\end{array}$ & $\begin{array}{l}\text { BAYDAR and BROOKS- } \\
\text { GUNN (1998) } \\
\text { UHLENBERG and } \\
\text { HAMILL (1998) }\end{array}$ \\
\hline $\begin{array}{l}\text { Gender } \\
\text { grandchild }\end{array}$ & Male & $n=411$ & $\begin{array}{l}\text { (Slightly) more } \\
\text { contact with grand- } \\
\text { daughters than } \\
\text { grandsons }\end{array}$ & EULER, HOIER and \\
& $n=420$ & & \\
\hline $\begin{array}{l}\text { Age grand- } \\
\text { parent }\end{array}$ & (interval) & & $\begin{array}{l}\text { Less contact if } \\
\text { older }\end{array}$ & BAYDAR and BROOKS- \\
\hline $\begin{array}{l}\text { Age grand- } \\
\text { child }\end{array}$ & (interval) & $\begin{array}{l}63.21 \text { years } \\
(\mathrm{SD}=7.59)\end{array}$ \\
\hline
\end{tabular}

et al. 1997; MCBURNEY et al. 2002 but see EULER and WEITZEL 1996) or sexspecific investment in matrilines (EULER and WEITZEL 1996; EULER and MICHALSKI, in press). LAHAM and colleagues (2005) explained higher investment by maternal grandfathers than paternal grandmothers in terms of the availability of more certain 'outlets'. If alternative investment options (e.g. cousins via a sister) are available to paternal grandmothers, they should invest less in grandchildren than maternal grandfathers do.

Differences between maternal grandmothers and paternal grandparents and between maternal grandfathers and paternal grandfathers would thus suggest that psychological mechanisms attuned to paternity uncertainty are operating. Differences between maternal grandfathers and paternal grandmothers can be explained by coresidence of grandparents, sex-specific investment strategies or available investment outlets.

\section{METHODS}

The first wave of the Netherlands Kinship Panel Study (NKPS) dataset was obtained through the Netherlands Interdisciplinary Demographic Institute (NIDI). The NKPS is a large scale longitudinal study, designed to investigate family and kin relations in the Netherlands (DYKSTRA et al. 2004). The first wave was completed mid-2004; we used the most recent version of the first wave dataset for this study (version of 21-7-05; main sample). The sampling procedure, representativity as well as the survey method is described in detail by DYKSTRA and colleagues (2004). The NKPS survey asks questions about contact frequencies with the oldest grandchild of a randomly selected child of the respondent. If this randomly selected child did not have any children, information was surveyed on the grandchild of the oldest child. Cases where information was surveyed on the grandchild of the oldest child, instead of on a randomly selected child, were excluded from analysis. As information about 
only one grandchild was surveyed, a core argument against surveying grandparents, i.e. consciously counterbalancing ratings (HOFFMAN 1979-1980; EULER and WEITZEL 1996), does not apply to this setup.

From this dataset we selected all individuals who had a grandchild between zero and fifteen years old at the time of the interview (mean $=6.45$ years; std $=4.23$ years). There is no data available on the genetic relatedness between the child and grandchild but only on genetic relatedness between grandparent and child. Five cases where the grandparent was never married were excluded from analysis, as this category is problematic for obtaining estimates in the multinomial logistic regression. Only cases where the grandchild was living with the child of the respondent were used and 'missings' on variables were treated list wise for the multinomial logistic regression (Final sample: $n=831$ ). The variables used are described in DYKSTRA and colleagues (2004), with the exception of constructed or recoded variables (age of grandchild, education, geographical distance, marital status grandparent). Initiative of contact, whether it was by the grandparent or by the parent of the grandchild, was surveyed as: 'When you're in touch with \{name, description\}, do you usually get in touch at your initiative, at the other's initiative, or is it more or less equal?' (DYKSTRA et al. 2004). The dependent variable, frequency of contact, was surveyed as: 'How often have you seen \{name, description\} over the past 12 months'. The variables used, their associated predictions and descriptives are summarized in Table 1.

Multinomial logistic regression (MLR) was used to investigate the independent effect of grandparental type on contact frequencies (HOSMER and LEMESHOW 1989; MENARD 1995; PAMPEL 2000). Multinomial logistic regression as statistical technique is relatively free of assumptions and statistically robust. Unlike ordinary least square regression parameters are estimated by maximum likelihood. As parameter selection procedure we used forward stepwise. Model outcomes were not different in terms of model fit and Nagelkerke R² (NAGELKERKE 1991) when backward stepwise was used instead. Here we will report the likelihood ratio tests for variables $\left(p_{\text {IIr }}\right)$ in the model and the parameter estimates for the models (see PENG et al. 2002). As we use many independent variables, we will not discuss all effects in detail. Our main focus is the estimates of effect size for grandparental type. ${ }^{2}$

\section{RESULTS}

Figure 1 shows significant differences in the distribution of contact frequencies by grandparent type. Overall the MLR model performs very well according to standards within the social sciences. The overall model has a Nagelkerke $R^{2}$ of 0.60 (Model Fit $\chi^{2}=705.92 ; \mathrm{df}=55 ; p<0.0001$; Table 2). From the variables in Table 1 , urbanisation, attained level of education, marital status of the child, relatedness to

\footnotetext{
${ }^{2}$ The parameter estimates not represented here can be requested from the corresponding author.
} 


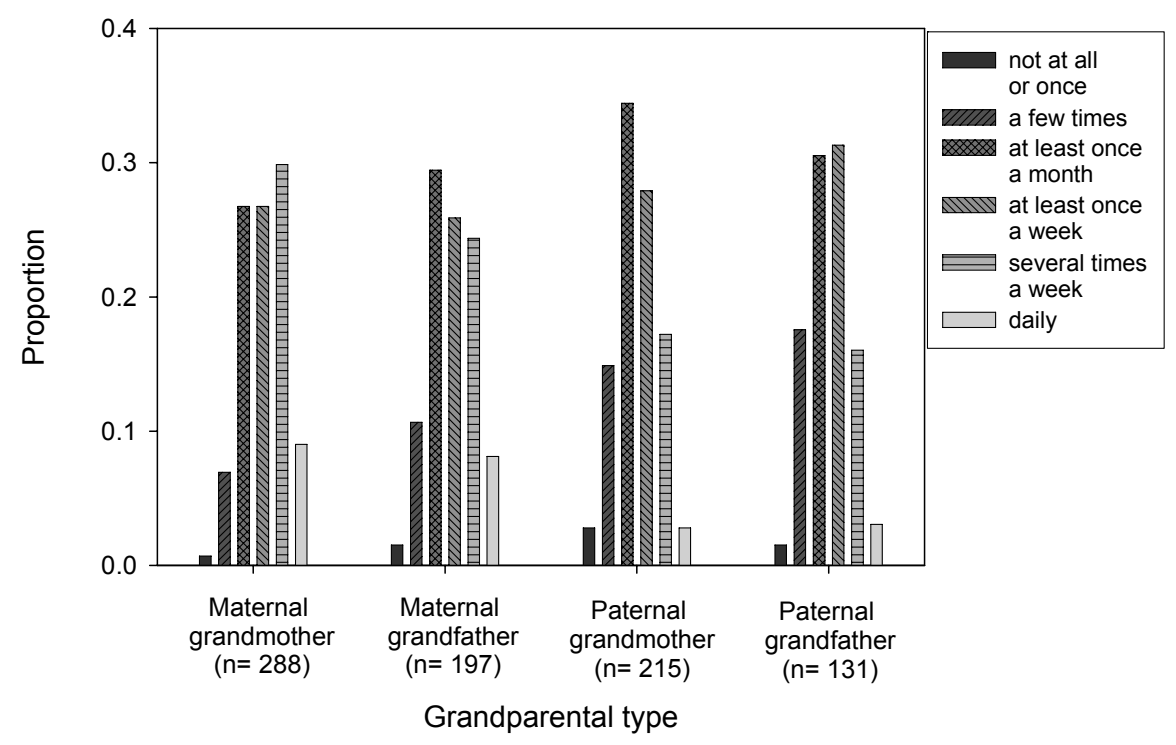

Figure 1. Distribution of contact frequencies by grandparental type;

Note: $\chi^{2}=39.12 ; \mathrm{df}=15 ; p<0.001$

Table 2. parameter estimates $(\lambda)$ and odds ratios $(\exp (\lambda))$ for MLR with reference category of dependent variable is "not at all or once". The Wald statistic allows examining the significance of individual parameters. The likelihood ratio tests $\left(p_{\mathrm{llr}}\right)$ evaluate the significance of a variable.

Reference categories for independent categorical variables have parameter estimates set to 0 .

\begin{tabular}{|c|c|c|c|c|c|c|c|c|}
\hline Contact & A few times a week & $\lambda$ & Std. Error & Wald & df & $p_{\text {Wald }}$ & $\operatorname{Exp}(\lambda)$ & $p_{\mathrm{LLR}}$ \\
\hline & Intercept & 5.92 & 2.97 & 3.98 & 1 & 0.046 & & \\
\hline \multirow{3}{*}{$\begin{array}{l}\text { Marital status } \\
\text { (grandparent) }\end{array}$} & Widowed & -3.11 & 0.98 & 10.15 & 1 & 0.001 & 0.04 & $<0.001$ \\
\hline & Divorced & -4.32 & 0.99 & 19.16 & 1 & $<0.001$ & 0.01 & \\
\hline & Married & 0 & . & & 0 & 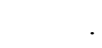 & . & \\
\hline \multirow[t]{3}{*}{ Initiative contact } & Initiative grandparent & -1.24 & 1.06 & 1.36 & 1 & 0.244 & 0.29 & 0.001 \\
\hline & Balanced & 0.87 & 1.00 & 0.77 & 1 & 0.381 & 2.39 & \\
\hline & Initiative parent & 0 & . & & 0 & & & \\
\hline Geograph. distance & (increase by one km) & -0.16 & 0.02 & 65.00 & 1 & $<0.001$ & 0.85 & $<0.001$ \\
\hline Age grandchild & (increase by one year) & -0.06 & 0.10 & 0.35 & 1 & 0.555 & 0.94 & 0.002 \\
\hline Age grandparent & (increase by one year) & 0.03 & 0.05 & 0.45 & 1 & 0.503 & 1.03 & $<0.001$ \\
\hline Number of children & (increase by one child) & -0.72 & 0.22 & 10.94 & 1 & 0.001 & 0.49 & $<0.001$ \\
\hline \multirow[t]{4}{*}{ Grandparental type } & Maternal grandmother & 1.95 & 0.90 & 4.71 & 1 & 0.030 & 7.05 & $<0.001$ \\
\hline & Maternal grandfather & 0.72 & 0.83 & 0.74 & 1 & 0.391 & 2.05 & \\
\hline & Paternal grandfather & -0.54 & 0.97 & 0.31 & 1 & 0.577 & 0.58 & \\
\hline & Paternal grandmother & 0 & . & & 0 & . & . & \\
\hline
\end{tabular}


Table 3. Odds ratios $(\exp (\lambda))$ for comparisons between grandparent types and contact frequencies. $*: p<0.05 ; * *: p<0.01 ; * * *: p<0.001$ (Wald statistic).

\begin{tabular}{|c|c|c|c|c|c|c|}
\hline & & $\begin{array}{l}\text { a few } \\
\text { times }\end{array}$ & $\begin{array}{l}\text { at least } \\
\text { once a } \\
\text { month }\end{array}$ & $\begin{array}{c}\text { at least } \\
\text { once a } \\
\text { week }\end{array}$ & $\begin{array}{c}\text { a few times } \\
\text { a week }\end{array}$ & daily \\
\hline \multirow{6}{*}{$\begin{array}{l}\text { not at all } \\
\text { or once }\end{array}$} & MGM vs MGF & n.s. & n.s. & n.s. & n.s. & n.s. \\
\hline & MGM vs PGM & n.s. & n.s. & n.s. & $7.05 *$ & $13.97 * *$ \\
\hline & PGF vs PGM & n.s. & n.s. & n.s. & n.s. & n.s. \\
\hline & MGF vs PGM & n.s. & n.s. & n.s. & n.s. & n.s. \\
\hline & MGM vs PGF & n.s. & n.s. & n.s. & $12.08 *$ & $19.94 *$ \\
\hline & MGF vs PGF & n.s. & n.s. & n.s. & n.s. & n.s. \\
\hline \multirow{6}{*}{ a few times } & MGM vs MGF & - & n.s. & n.s. & n.s. & n.s. \\
\hline & MGM vs PGM & - & n.s. & $2.95 * *$ & $6.77 * * *$ & $13.42 * * *$ \\
\hline & PGF vs PGM & - & n.s. & n.s. & n.s. & n.s. \\
\hline & MGF vs PGM & - & n.s. & n.s. & n.s. & $5.65 * *$ \\
\hline & MGM vs PGF & - & $3.23 * *$ & $3.71 * *$ & $9.39 * * *$ & $15.49 * * *$ \\
\hline & MGF vs PGF & - & n.s. & n.s. & $3.34 *$ & $6.52 *$ \\
\hline \multirow{6}{*}{$\begin{array}{l}\text { at least } \\
\text { once a } \\
\text { month }\end{array}$} & MGM vs MGF & - & - & n.s. & n.s. & n.s. \\
\hline & MGM vs PGM & - & - & n.s. & $3.35 * * *$ & $7.01 * * *$ \\
\hline & PGF vs PGM & - & - & n.s. & n.s. & n.s. \\
\hline & MGF vs PGM & - & - & n.s. & $2.47 *$ & $5.81 * *$ \\
\hline & MGM vs PGF & - & - & n.s. & $2.91 * *$ & $4.79 *$ \\
\hline & MGF vs PGF & - & - & n.s. & n.s. & $3.97 *$ \\
\hline \multirow{6}{*}{$\begin{array}{c}\text { at least } \\
\text { once a } \\
\text { week }\end{array}$} & MGM vs MGF & - & - & - & n.s. & n.s. \\
\hline & MGM vs PGM & - & - & - & $2.27 * *$ & $4.48 * *$ \\
\hline & PGF vs PGM & - & - & - & n.s. & n.s. \\
\hline & MGF vs PGM & - & - & - & $1.93 *$ & $4.53 * *$ \\
\hline & MGM vs PGF & - & - & - & $2.51 * *$ & $4.14^{*}$ \\
\hline & MGF vs PGF & - & - & - & $2.14 *$ & $4.18 *$ \\
\hline \multirow{6}{*}{$\begin{array}{c}\text { a few } \\
\text { times } \\
\text { a week }\end{array}$} & MGM vs MGF & - & - & - & - & n.s. \\
\hline & MGM vs PGM & - & - & - & - & n.s. \\
\hline & PGF vs PGM & - & - & - & - & n.s. \\
\hline & MGF vs PGM & - & - & - & - & n.s. \\
\hline & MGM vs PGF & - & - & - & & n.s. \\
\hline & MGF vs PGF & - & - & - & & n.s. \\
\hline
\end{tabular}


the child and the gender of grandchild did not prove significant predictors at five percent significance level. Relatedness to the child is however marginally significant in the predicted direction $\left(\chi^{2}=10.1 ; \mathrm{df}=5 ; p_{\text {llr }}=0.072\right.$; difference in Nagelkerke $R^{2}=0.005$ ). The absence of a strong effect for relatedness could be explained by the low number of cases in the sample where the grandparent was unrelated to his or her child $(n=14)$. Table 2 shows the likelihood ratio tests for the variables in the model and the parameter estimates.

Parameters are best interpreted in terms of odds ratios $(\exp (\lambda))$ (PAMPEL 2000). Maternal grandmothers are 7.05 times more likely than paternal grandmothers to have had contact a few times a week instead of 'not at all or once' over the past twelve months (Table 2). Maternal grandmothers are 19.94 times more likely than paternal grandfathers to have had contact daily instead of 'not at all or once' over the past twelve months (Table 3).

By substituting reference categories for grandparents and for face-to-face contact frequency, we obtained estimates for comparisons across contact and grandparental categories.

\section{DISCUSSION}

In line with LAWTON, SILVERSTEIN and BENGSTON (1994), we found a significant effect of geographical distance between grandparent and grandchild on their interaction. In contrast to findings from the USA (KING and ELDER 1995; KING et al. 2003), urbanization appeared relatively unimportant for contact with grandchildren. This could be attributed to the high level of urbanisation and population density in the Netherlands. Consistent with previous research within family studies and evolutionary predictions we found some indications for the influence of relatedness. Yet, the effect for genetic relatedness was only marginally significant. The lack of a strong finding could be explained by the low number of cases (only 14 cases) and by the fact that the category not fully related contained adopted children as well as children from the partner of the respondent's child. Aside from the predictions for educational attainment, urbanization, relatedness, marital status of the child and gender of the grandchild, the predictions made in Table 1 based on previous research are replicated in this model.

Consistent with predictions on paternity uncertainty, we find strong differences between PGM and MGM, PGF and MGM and berween PGF and MGF. The differences between MGF and MGM as well as PGF versus PGM were not significant. This appears at odds with the paternity uncertainty hypothesis but can be explained by the effect of marriage and co-residence of grandparents: when grandchildren have contact with one of their grandparents, they usually meet the partner of the married grandparent as well (see GAULIN et al. 1997; MCBURNEY et al. 2002; but see EULER and WEITZEL 1996). 
The odds ratios reveal quite strong differences between maternal and paternal grandparents for comparisons between certain categories (ranging from nearly double, likelihood of having contact several times a week instead for MGF versus PGM, to nearly twenty times, likelihood of have daily contact instead of once or not at all for MGM versus PGF). Similar to EULER and WEITZEL (1996), we found that MGF had more frequent contact than PGM. We can thus concur that differences in the ascribed role of grandmothers do not account for grandparental solicitude as observed in contact frequencies. Such a difference can be explained by co-residence of grandparents (see GAULIN et al. 1997; MCBURNEY et al. 2002 but see EULER and WEITZEL 1996), sex-specific investment (EULER and WEITZEL 1996; EULER and MICHALSKI, in press) or the availability of alternative investment outlets (LAHAM et al. 2005). Contrary to MiCHALSKI and SHACKELFORD (2005), we find consistent differences in contact frequency not only between MGM and PGF but also between other comparisons (MGM vs. PGM; MGF vs. PGM; MGF vs. PGF). In conclusion, our results show that biases in contact frequencies are in line with predictions based on paternity uncertainty. This finding appears robust and cannot be attributed to the other factors affecting the grandparent-grandchild tie described in Table 1.

\section{CONCLUSIONS}

In line with predictions from evolutionary theory, we find that differences between grandparents in paternity uncertainty also influence interaction frequencies between grandparent and grandchild. While controlling for a wide range of variables maternal grandparents are shown to have significantly more frequent contact with their grandchildren than paternal grandparents. Biases in grandparental investment, according to paternity uncertainty are thus also evident from interactions between grandparents and grandchildren.

\section{Acknowledgments}

The authors wish to thank Joan Silk, Virpi Lummaa, Steve Gaulin, the participants of the ICEG workshop and Harald Euler for valuable comments which substantially improved earlier drafts. We also wish to thank Netherlands Interdisciplinary Demographic Institute (NIDI) for access to the NKPS data.

'The Netherlands Kinship Panel Study is funded by grant 480-10-009 from the Major Investments Fund of the Netherlands Organization for Scientific Research (NWO), and by the Netherlands Interdisciplinary Demographic Institute (NIDI), Utrecht University, the University of Amsterdam and Tilburg University'. 


\section{REFERENCES}

ANDERSON, K.G. (2006): How well does paternity confidence match actual paternity? Evidence from worldwide nonpaternity rates. Current Anthropology, 48, 511-518.

BARRANTI, C. C. R. (1985): The grandparent/grandchild relationship: Family resource in an era of voluntary bond. Family Relations, 34, 343-352.

BAYDAR, N. and BROOKS-GunN, J. (1998): Profiles of grandmothers who help care for their grandchildren in the United States. Family relations, 47, 385-393.

BeCK, U. (1993 [1992]): The Risk Society. London: Sage.

BECK, U. and BECK-GERNSHEIM, E. (2002): Individualization. London: Sage.

Chrastil, E., Getz, W. M., Euler H. A. and Stark, P. T. (2006): Paternity uncertainty overrides sex chromosome selection for preferential grandparenting. Evolution and Human Behavior, 27, 206-223.

Denham, T. E. and Smith, C. W. (1989): The influences of grandparents on grandchildren: A review of the literature and resources. Family Relations, 38, 345-350.

Dykstra, P. A., Kalmijn, M., Knijn, T. C. M., Komter, A. E., Liefbroer, A. C. and Mulder, C. H. (2004): Codebook of the Netherlands Kinship Panel Study, a multi-actor, multimethod panel study on solidarity in family relationships, Wave 1. NKPS Working Paper No. 1. The Hague: Netherlands Interdisciplinary Demographic Institute. (version of July 2005).

EISENBERG, A. R. (1988): Grandchildren's perspectives on relationships with grandparents: The influence of gender across generations. Sex Roles, 19, 205-217.

Euler, H. A. and Weitzel, B. (1996): Discriminative grandparental solicitude as a reproductive strategy. Human Nature, 7, 39-59.

Euler, H. A., HoIER, S. and RoHDE, P. A. (2001): Relationship-specific closeness of intergenerational family ties: Findings from evolutionary psychology and implications for models of cultural transmission. Journal of Cross-Cultural Psychology, 32, 147-158.

Euler, H. A. and MiChALSKI, R. (in press): Grandparental and extended kin relationships. In C. Salmon and T. K. Shackelford (eds.): Family relationships: an evolutionary perspective. Oxford, UK: Oxford University Press.

Gaulin, S. J. C., McBurney, D. H. and Brakeman-Wartell, S. L. (1997). Matrilateral biases in the investment of aunts and uncles: A consequence and measure of paternity uncertainty. Human Nature, 8, 139-152.

Gibson, M. and MACE, R. (2005): Helpful grandmothers in rural Ethiopia: A study of the effect of kin on child survival and growth. Evolution and Human Behavior, 26, 469-482.

GidDEnS, A. (1991): Modernity and Self identity. London: Polity.

HAmiLton, W. D. (1964): The genetical evolution of social behaviour I, II. Journal of Theoretical Biology, 7, 1-52.

HofFMAN, E. (1979-1980): Young adults' relationship with their grandparents: An exploratory study. International Journal of Aging and Human Development, 10, 299-310.

Hosmer, D. and Lemeshow, S. (1989): Applied Logistic Regression. New York: Wiley and Sons.

House, J. S., Umberson, D. and LANDis, K. R. (1988): Structures and processes of social support. Annual Review of Sociology, 14, 293-318.

JoHNSON, C. L. (1988): Postdivorce reorganization of relationships between divorcing children and their parents. Journal of Marriage and the Family, 50, 221-231.

KAHANA, B. and KAHANA, E. (1970): Grandparenthood from the perspective of the developing grandchild. Developmental Psychology, 3, 98-105.

KING, V. (2003): The Legacy of a Grandparent's Divorce: Consequences for Ties Between Grandparents and Grandchildren. Journal of Marriage and the Family, 65, 170-183.

KING, V. and ElDER, G. H. (1995): American children view their grandparents: Linked lives across three rural generations, Journal of Marriage and the Family, 57, 165-178. 
King, V., Silverstein, M., Elder, G. H., Bengston, V. L. and Conger, R. D. (2003): Relations with Grandparents: Rural Midwest versus Urban Southern California. Journal of Family Issues, 24, 1044-1069.

KivetT, V. R. (1985): Grandfathers and grandchildren: Patterns of association, helping and psychological closeness. Family Relations, 34, 565-571.

Laham, S. M., Gonsalkorale, K. and von HipPel, W. (2005): Darwinian grandparenting: Preferential investment in more certain kin. Personality and Social Psychology Bulletin, 31, $63-$ 72.

LahdenPerÄ, M., LummaA, V., Helle, S., Tremblay, M. and Russell, A. F. (2004): Fitness benefits of prolonged post-reproductive lifespan in women. Nature, 428, 178-181.

Lawton, L., Silverstein, M. and Bengston, V. (1994): Affect, Social Contact, and Geographic Distance between parents and their adult children. Journal of Marriage and the Family, 56, $57-68$.

McBurney, D. H., Simon J., Gaulin, S. J. C. and Geliebter, A. (2002): Matrilateral biases in the investment of aunts and uncles replication in a population presumed to have high paternity certainty, Human Nature, 13, 391-402.

Menard, S. (1995): Applied Logistic Analysis, Quantitative Applications in the Social Sciences Series \#106. Thousand Oaks: Sage Publications.

MiCHALSKI, R. L. and SHACKELFORD, T. K. (2005): Grandparental investment as a function of relational uncertainty and emotional closeness with parents. Human Nature, 16, 293-305.

NagelKerke, N. J. D. (1991): A note on a general definition of the coefficient of determination. Biometrika, 78, 691-692.

PAMpel, F. C. (2000): Logistic regression: A primer, Quantitative Applications in the Social Sciences Series \#132. Thousand Oaks: Sage Publications.

Pashos, A. (2000): Does paternity uncertainty explain discriminative grandparental solicitude? A cross-cultural study in Greece and Germany. Evolution and Human Behavior, 21, 97-109.

Peng, C.-Y. J., Lee, K. L. and Ingersoll, G. (2002): An Introduction to Logistic Regression Analysis and Reporting. Journal of Educational Research, 96, 1-14.

RagSDAle, G. (2004): Grandmothering in Cambridgeshire, 1770-1861. Human Nature, 15, 301317.

Reitzes, D. C. and Mutran, E. J. (2004): Grandparenthood: Factors influencing frequency of grandparent-grandchildren contact and grandparent role satisfaction. Journal of Gerontology B, 59B, S9-S16.

Rossi, A. S. and Rossi, P. H. (1990): Of human bonding: Parent-child relations across the Life course. New York: Aldine.

SANDERS, G.F. and TRYGSTAD, D.W. (1989): Stepgrandparents and Grandparents: The View from Young Adults, Family Relations, 38, 71-75.

SEAR, R., MACE, R. and MCGREgor, I. A. (2000): Maternal grandmothers improve nutritional status and survival of children in rural Gambia. Proceedings of the Royal Society London B, 267, 1641-1647.

Sear, R., Steele, F., McGregor, I. A. and Mace, R. (2002): The effects of kin on child mortality in rural Gambia. Demography, 39, 43-63.

UhlenBerg, P. and HAMill, B.G. (1998): Frequency of grandparent contact with grandchild sets: Six factors that make a difference. Gerontologist, 38, 276-285.

VOLAND, E. and BEISE, J. (2002): Opposite effects of maternal and paternal grandmothers on infant survival in historical Krummhörn. Behavioral Ecology and Sociobiology, 52, 435443. 